\title{
Activity-based costing in smart and connected products production enterprises
}

\author{
Marisa Sánchez $^{\mathrm{a}}$, María de la Paz Moral ${ }^{\mathrm{a}}$ and Gustavo Ramoscelli ${ }^{\mathrm{b}}$
}

${ }^{a}$ Dpto. de Ciencias de la Administración, Universidad Nacional del Sur, Argentina ${ }^{b}$ Dpto. de Ingeniería Eléctrica y de Computadoras, Universidad Nacional del Sur, Argentina

\begin{tabular}{l}
\hline C H R O N I C L E \\
\hline Article history: \\
Received May 172019 \\
Received in revised format June \\
22019 \\
Accepted June 22019 \\
Available online \\
June 4 2019 \\
\hline Keywords: \\
Internet of Things \\
Smart and connected products \\
Activity-based Costing \\
Business Model Patterns \\
Sensor as a Service pattern \\
Digitally Charged Products \\
pattern
\end{tabular}

\section{A B S T R A C T}

The purpose of this paper is to investigate the adoption of an Activity-Based Costing (ABC) system to provide relevant cost information for enterprises in the business of building and selling Internet of Things (IoT) based products. The research is constructed over the relevant themes identified in previous research about ABC. An important issue that emerges from the analysis is that cost is a function of the volume of production and this notion of production does not represent the source of value generation discussed in this work. A functioning of a smart and connected product requires a cloud-based system for operating and monitoring it throughout its life. The implication of collecting and processing data is that costs essentially changes depending on the volume of data stored and the complexity of intended analytics that would require more qualified analysts. The estimation of costs related to data analytics and products' monitoring serve as a reference to forecast future expending during the lifetime of products. This research is the first to provide a theoretical discussion on $\mathrm{ABC}$ assumptions in the context of IoT business models.

\section{Introduction}

The impact of the digital revolution derives from the extraordinary progress of technology and the opportunity for technology deployments to spread throughout the world. This is a time when technologies are demonstrating that they can do work that we have never thought of as pre-programmed or routine (McAfee \& Brynjolfsson, 2017). Organizations are experiencing a transformation. In particular, the Internet of Things links products to sensors creating new opportunities to create value or reduce costs. Porter and Heppelmann (2014) observe the information technology has become part of the product itself. Products enabled by the Internet of Things can monitor users' utilization and satisfaction and represent an opportunity for manufacturers to create new business models that change the focus from independent product offers to services. Companies which intend to develop their digital capabilities (i.e., their ability to generate business value from digital technologies) have to engage in a simultaneous re-design of both technology and business artefacts in order to be successful (Westerman, Bonnet, \& McAfee, 2014). In the course of the digital transformation, business models are adapted or reinvented. On the other hand, since IoT-based solutions are relatively new phenomena, literature that explains how organizations calculate the return on investment and justify costs estimation is scarce.

\footnotetext{
* Corresponding author.

E-mail address: mas@uns.edu.ar (M. Sánchez) 
Every business model representation captures key aspects such as why the business model is financially interesting. Many authors have proposed business models patterns and a key component is an explanation on why the model is financially viable. The revenue model unifies aspects such as the cost structure and the applied revenue mechanisms, and point to the elementary question of any firm, namely how to make money in the business (Gassmann, Frankenberger, \& Csik, 2014). Hence, it is reasonable to discuss the most appropriate cost management issues arising from IoT business models patterns.

The Activity-based costing is a costing system that provides relevant information for decision making. The model emerged as a response on the need to better assess costs in modern production environments and by virtue of dissatisfaction with variable costing and traditional costing for not meeting the expectations and needs of managers. In this work, small enterprises in the business of building and selling IoT-based products are considered. These companies may rely on different costing systems from traditional manufacturing firms. Hence, the aim of this work is to discuss the adoption of an ActivityBased Costing $(\mathrm{ABC})$ system to provide relevant cost information for enterprises in the business of building and selling IoT-based products. In other words, the necessary and sufficient conditions under which $\mathrm{ABC}$ product costs represent avoidable product costs and $\mathrm{ABC}$ overhead rates represent incremental activity costs.

In order to discuss the adoption of an $\mathrm{ABC}$ system to provide relevant cost information for enterprises in the business of building and selling IoT-based products, it is necessary to consider research about ABC assumptions. Also, in order to conceptualize a proposal for cost management we should first reflect upon what a digital transformation means for an organization: which are the core decisions in short and long term. The discussion is constructed over the relevant themes identified in previous ABC research (Orwat et al., 2008; Weiser, 1991).

The remainder of this paper is organized as follows. The next section reviews relevant concepts regarding digital transformation, IoT business model patterns and $\mathrm{ABC}$ costing. The following section provides a theoretical discussion on the adoption of an $\mathrm{ABC}$ system to provide relevant cost information for enterprises in the business of building and selling IoT-based products. Section 4 presents an illustrative example of an organization's $\mathrm{ABC}$ cost system definition. The final section includes a summary and discusses the implications.

\section{Theoretical Background}

\subsection{What digital transformation means to a business}

In order to conceptualize a proposal for cost management we should first reflect upon what a digital transformation means for an organization. As pointed out by Govindarajan and Immelt (2019), many CEOs miss the fact that a digital transformation is not the same as the digitalization of an existing business. It isn't about infusing information technology into the organization but a digital transformation entails reimaging products and services as digitally enabled assets; generating new value from the interconnection of physical and digital assets through data; and creating ecosystems to make that possible (Govindarajan \& Immelt, 2019). To effectively build and sell IoT, a traditional enterprise must transform itself in almost every way it does business. Manufacturing now goes beyond the production of the physical object, because a functioning smart, connected product requires a cloudbased system for operating it throughout its life (Porter \& Heppelmann, 2015). At a high level every company will become part of the computer industry. Operationally, these changes affect every department: engineering, data, manufacturing, marketing, sales, support and maintenance, business development, human resources, and legal (Sinclair, 2017).

IoT data-driven marketing begins with building and then analyzing the utility (what a product is used for) and usability (how the product is being used) models of the product. These models may be used to make existing products better, to create new products, to prioritize product features and updates, to personalized contextualized messages based on consumer use cases. 
IoT based products change the traditional role of sales: what is sold, how it's sold, and to whom it is sold. The ability to remain connected to the product and track how it's being used shifts the focus of a company's customer relationship from selling - often a predominantly onetime transaction-to maximizing the customer's value from the product over time (Porter \& Heppelmann, 2015). There is a shift to outcome based selling. For example, in Rolls-Royce's "power-by-the-hour" model, airlines pay for the time jet engines are used in flight, rather than a fixed price plus charges for maintenance and repairs (Porter \& Heppelmann, 2015). At the core of these changes is the IoT product's ability to quantify what is important to the customer (Sinclair, 2017). Manufacturers can capture value in two ways (Govindarajan \& Immelt, 2019). First, they can sell subscriptions and licenses for the software products they develop in order to analyze the data from usage and refine the performance of their machines. Second, digital-industrial companies can offer "success as a service" through guaranteed customer outcomes -safety, speed, fuel efficiency, zero operator errors, no scheduled downtime (Govindarajan \& Immelt, 2019).

Regarding maintenance, smart, connected products improve service and efficiency and enable a fundamental shift from reactive service to preventive, proactive and remote service (Porter $\&$ Heppelmann, 2015). The organizational structure of a traditional manufacturing firm is also transformed. The real-time feedback of IoT-based products challenges the traditional centralized command-and-control model of management in favour of distributed but highly integrated choices and continuous improvement (Porter \& Heppelmann, 2015). A new function responsible for managing and optimizing the ongoing performance of connected products after they have left the factory is required. Porter and Heppelman (2015) suggest defining a unit (referred to as Dev-ops) that organizes teams from Research and Development, Information Technology (IT), manufacturing, and service that shorten product-release-cycles, manage product updates and patches, and delivers new services and enhancements post sale. Another new functional unit focused on data management emerge (referred to as Unified Data). This unit consolidate data collection, aggregation, and analytics, and is responsible for making data available across functions and business units. Porter and Heppelmann (2015) also describe a new organizational unit responsible for managing the customer experience and ensuring that customers get the most from the product (named Customer Success Management). The unit is different from the traditional sales because it aims ensuring that the customer gets the most out of the product and that the customer is continuously satisfied. Others propose to make it part of an existing sales unit, separating the two sales functions, or just change the job descriptions of salespeople to include these responsibilities (Sinclair, 2017). Govindarajan and Immelt (2019) suggest having a Chief Data Officer (CDO) who focuses on external markets and can weave their knowledge into the context of a customer's business, helping the customer realize the commercial value of digital technologies. At the same time, the Chief Information Officer (CIO) must concentrate on increasing productivity inside the company.

\subsection{IoT Business Model Patterns}

In this technology-rich scenario, real world components interact with cyberspace via sensing, computing and communication elements, thus driving towards what is called the Cyber-Physical World (CPW) (Conti, et al., 2012). The CPW is characterized by a large number of mobile devices that the users bring around or that are spread into the environment. This scenario enables the automatic observation and measurement of human behavior and the data captured in this way supports data-driven dynamic adaptation of systems in response to observed user habits, preferences and routines.

Various concepts have been coined and promoted by different scholars and technologists. Olson et al. (2015) present a collective of concepts that are used in depicting future visions of society as affordable by technology. The term Internet of Things was introduced by Kevin Ashton in 1999 (Ashton, 2009). Ashton visualized that a physical world can be connected to the internet via sensors and actuators which are capable of providing real time information and hence benefit our lives. With time, this notion has been considerable broadened (Olson, Nolin, \& Nelhans, 2015). Gubbi et al. (Gubbi, Buyya, Marusic, \& Palaniswami, 2013) defined IoT as the interconnection of sensing and actuating devices providing 
the ability to share information across platforms through a unified framework, developing a common operating picture for enabling innovative applications.

Current application domains of IoT include home and personal (control of home equipment, smart sensors in healthcare), enterprise (RFID in retail, industrial ecosystems), utilities (smart grid and household metering), transport (smart traffic, automatic driven vehicles, and intelligent logistics).

The notion of business models in management literature and practice is quite relevant since it enables entrepreneurs and managers to create and capture value through activities. Value capture and value creation concepts aims to explain firms' performance and competitive advantage. Osterwalder and Pigneur (2005) identify the most common building blocks among business models in the literature which are structured in a Business Model Canvas. From this synthesis, nine blocks emerge (see Table $1)$.

Table 1

Business Model building blocks

\begin{tabular}{|c|c|c|}
\hline Pillar & Business Model building block & Description \\
\hline Product & Value proposition & $\begin{array}{l}\text { Gives an overall view of a company's bundle of products } \\
\text { and services }\end{array}$ \\
\hline \multirow[t]{3}{*}{ Customer interface } & Target customer & $\begin{array}{l}\text { Describes the segments of customers a company wants to } \\
\text { offer value to. }\end{array}$ \\
\hline & Distribution channel & $\begin{array}{l}\text { Describes the various means of the company to get in touch } \\
\text { with its customers. }\end{array}$ \\
\hline & Relationship & $\begin{array}{l}\text { Explains the kind of links a company establishes between } \\
\text { itself and its different customer segments. }\end{array}$ \\
\hline \multirow{3}{*}{$\begin{array}{l}\text { Infrastructure } \\
\text { management }\end{array}$} & Value configuration & Describes the arrangement of activities and resources. \\
\hline & Core competency & $\begin{array}{l}\text { Outlines the competencies necessary to execute the } \\
\text { company's business model. }\end{array}$ \\
\hline & Partner network & $\begin{array}{l}\text { Portrays the network of cooperative agreements with other } \\
\text { companies necessary to efficiently offer and } \\
\text { commercialize value. }\end{array}$ \\
\hline \multirow[t]{2}{*}{ Financial aspects } & Cost structure & $\begin{array}{l}\text { Sums up the monetary consequences of the means } \\
\text { employed in the business model. }\end{array}$ \\
\hline & Revenue model & $\begin{array}{l}\text { Describes the way a company makes money through a } \\
\text { variety of revenue flows. }\end{array}$ \\
\hline
\end{tabular}

Source: (Osterwalder, Pigneur, \& Tucci, 2005)

The concept of "business model patterns" have gained wide acceptance in business model design. The business model patterns emphasize a number of specific design ideas, and they detail them using companies having successfully implemented them as examples (Blaschke et al., 2017). Blaschke et al. (2017) discuss how digital capabilities generate value and introduce the concept of digital value drivers. Digital value drivers (for example, on-demand services, target micro-segments) focus on particular business model components and digital key elements. According to Cevik and Ustundag (2018), smart and connected product business model differentiate from the traditional business models regarding the value proposition, revenue streams and technologies. The authors propose a classification framework for IoT business models based on these three components. The value proposition is classified based on Guo et al.'s (2017) classification that includes novelty-centered, efficiency-centered, lock-in centered and complementary values. A rising trend in IoT-oriented business models research is the ecosystem perspective, which emphasizes the complexity of the business environment for digital technologies, stressing the contextual issues such as interdependencies, interactions and partnerships that evolve in the same innovation ecosystem (Metallo et al., 2019).

Based on a comprehensive research over 300 companies, Gassman et al. (2014) introduce 55 generic business model patterns. Then, Fleisch et al. (2014) select 20 out of the 55 patterns that could profit significantly from the IoT. More recently, Weinberg et al. (2016) introduce the concept of highresolution management (HRM) which refers to the capability of achieving higher efficiency, quality and flexibility. IoT enables the collection of high-resolution data for the physical world where, as in 
the digital world, every aspect of business operations can be measured in real-time. Weinberg et al. (2016) analyzed business model patterns from Gassmann and many IoT applications with regard to their value creating steps and HRM. As a result of this analysis the authors identified six key components inherent to IoT business models and two independent business model patterns. The patterns are "Digitally charged products" and "Sensor as a Service". The "Digitally charged products" pattern components are all variations of the idea that the IoT in its applications links digital services to physical products to create a hybrid bundle that is a single whole (Fleisch, Weinberg, \& Wortman, 2014). The components are named as Digital add-on, Digital lock-in, Product as a point of sales, Physical freemium, Object self service and Remote usage and condition monitoring. The "Sensor as a Service" pattern describes the idea of collecting, processing and selling for a fee the sensor data from one subsection to other subsections. The measurement data from the physical world are no longer vertically integrated, collected, stored and processed for just one application but instead for a broad array of potential applications (Fleisch, Weinberg, \& Wortman, 2014). The business model pattern according to Gassmann et al. (2014) is "Leverage Customer Data" which refers to the case where new value is created by collecting customer data and preparing it in beneficial ways for internal usage or interested third parties. Revenues are generated by either selling this data directly to others or levering it for own purposes (Gassmann et al., 2014). Ahmed (2014) extends the Business Model Canvas proposed by Osterwalder and Pigneour with The Innovation Canvas. It is a framework that guides teams to develop integrated product designs and business models. There are some different templates to guide the value proposition development (Canvanizer 2.0, 2017), (Willness \& Bruni-Bossio, 2017). The canvas itself supports a number of design tools, methods, and approaches (Kline, et al., 2013). The Innovation Canvas incorporates all the themes of the business Model Canvas in the Market quadrant. The Explore, Ideate and Design quadrants have been added to include the key themes of a meta-model of a system and are described as follows:

- The Explore section provides a detailed description of the project goals, collect stakeholder and voice of the customer input, clarify benefits and values of a product and provide context for the project.

- The Ideate section describes what the product will do and the external systems that the product interacts with.

- The Design section includes a formal requirements analysis, key components or modules, critical success factors of the product, and critical risks of product failure that require special attention.

- The Market section includes the nine constructs from the Business Model Canvas (Osterwalder \& Pigneur, 2010).

\subsection{Activity-Based Costing}

The Activity-Based Costing (ABC) has become known from the 80 s is a costing system that emerged as a response on the need to better assess costs in production environments that incorporated the philosophy of Lean Manufacturing to minimize waste and optimize their production process. $\mathrm{ABC}$ proposes for organizations an understanding of cause and effect between the costs and activities needs, in addition to direct costs of these activities to costs objects (Askarany et al., (2010) as cited in Medeiros et al., 2017). Miller and Vollman showed that output volume did not drive overhead costs, and that overhead drivers were associated with organizational transactions such as logistics, balancing (meeting purchasing, materials planning, and human resource requirements), quality (engineering and quality control), and change (engineering change orders) (Gosselin, 2007).

$\mathrm{ABC}$ systems are based on the notion that products incur costs by giving raise to activities, which generate costs (Noreen, 1991). ABC is a two stage accounting technique. First, an organization needs to identify significant activities and to assign indirect costs to these activities in accordance with the way resources are consumed by these activities. In the second stage, indirect costs allocated to activities or activity cost pools are assigned to products, services, or any other cost objects in proportion to the 
amount of the cost driver consumed by each of them (Hilton, 2005). Gosselin (2007) observes that since costs are grouped in a pool corresponding to the activity that is performed, then the focus is on why the costs were incurred instead of where.

A few years after its emergence, both academics and practitioners started to observe that providing financial and non-financial information on activities and cost drivers could also have important management implications. Consequently, the concept of activity Based Management first appeared in 1991 (Gosselin, 2007).

Research on adoption of $\mathrm{ABC}$ and its impact on performance, reveal mixed results (Gosselin, 2007). Previous works reports $\mathrm{ABC}$ difficulties like continuous effort of employees in its preparation (Medeiros, Santana, \& Guimarães, 2017). However, these survey studies date from more than ten years old and hence results are not necessarily valid today. Also, the value chain, the business model and the market of the unit of analysis considered in the studies are not the same of a smart and connected products manufacturing firm. In this paper we aim to answer in what extent it is sensible to rely on $\mathrm{ABC}$ cost data for pricing, product drop, make or buy, or outsourcing decisions. Eric Noreen (1991) identified three conditions under which $\mathrm{ABC}$ provides relevant cost information. In this paper we discuss these conditions in the context of a firm that aims to build and sell smart and connected products. However, in order to conceptualize a proposal for cost management we should first reflect upon what a digital transformation means for an organization. Next section provides some clues with the aim of describing to the reader the kind of emerging decisions in this context.

\section{Assumptions on $\mathrm{ABC}$ in the context of smart and connected products}

The aim of this section is to discuss the adoption of an $\mathrm{ABC}$ system to provide relevant cost information for enterprises in the business of building and selling IoT-based products. Noreen (1991) defined the necessary and sufficient conditions for the relevance of activity-based costs. In other words, the necessary and sufficient conditions under which $\mathrm{ABC}$ product costs represent avoidable product costs and $\mathrm{ABC}$ overhead rates represent incremental activity costs. The avoidable cost of a product is defined to be the change in total cost if the product were dropped, keeping the volumes of all other products the same (Noreen, 1991). The main reason of analyzing these conditions is to understand how to define an allocation scheme in which cost drivers are correctly identified and measured on at least the aggregate level. Also, to understand which costs cannot be adequately represented by ABC.

Bromwich and Hong (1999) extend Noreen's work and investigate what conditions must be placed upon technology and prices to more generally satisfy Noreen's conditions. The analysis that follows is structured according to Bromwich and Hong's (1999) definitions and the mathematics is kept to a minimum. A central objective of management accounting is to seek the optimal organization of production, consumption and exchange in order to maximize profits and net worth. The starting point for looking analytically at the economics of the firm is to model the cost structure of the firm (Bromwich, 2007). The definition of cost structure is based on management accounting that focuses on production and hence a cost function for a multi-product firm can be written as:

$$
c(w, y)=\min \{w x \mid x \in V(y), x \geq 0\},
$$

where $w$ is an input price vector, $y$ an output vector and $x$ an input vector. $V(y)$ is the input requirement set comprising all input combinations capable of producing output $y$ and includes the optimal technology for each combination of inputs. Often in models, this optimal technology is expressed as a production function (Bromwich, 2007). Costs are minimized by choosing those non-negative inputs $(x)$ within the available technology, which minimize the cost of producing the desired output $(y)$.

This model of cost structure is very general and can incorporate linear and nonlinear technologies and common and joint costs (Bromwich, 2007). The ABC definition of the cost function requires restrictions to be placed on the assumed behavior of prices and technology. Bromwich and Hong (1999) use the concept of accounting separability to determine the conditions, which need to be imposed on $\mathrm{ABC}$ to be legitimately used to minimize costs. The property of accounting separability allows the cost 
function to be written in disaggregated forms and the first stage for a two-stage costing system can be written in the following way:

$$
c(w, y)=c^{1}(w, y)+c^{2}(w, y)+\cdots+c^{K}(w, y) \text {, }
$$

where $c^{k}(w, y)$ for $k \in\{1, \cdots, K\}$ represents the total cost of cost pool $k$. By summing the cost pools used by product $j$, its product cost can be represented in a number of ways as:

$$
c_{j}\left(w, y_{j}\right)=\sum_{k} c_{j}^{k}\left(w, y_{j}\right)=\sum_{k} w^{k} x^{k}\left(w, y_{j}\right)=\sum_{k} p^{k} h_{j}^{k}\left(x^{k}\right),
$$

where $h^{k}\left(x^{k}\right)$ represents the cost driver as a function of the input vector $x$. The cost function is assumed to be well behaved in that it satisfies the usual restrictions imposed on cost functions in economic theory (Chambers, 1988). In order for a cost function to reflect cost minimizing results, the individual product cost functions $c_{j}$ must satisfy two conditions:

I. The costs generated by the costing system must equal the incremental or avoidable costs of the output to which the cost function applies. This condition for $\mathrm{ABC}$ implies independent cost pools and that non-jointness exists between cost objects.

II. The separable cost of each product is equal to its stand alone cost. This is one condition for being able to treat cost pools and costs for products as independent of other costs and products.

Smart and connected products are composed of three main components: software, hardware and communications. The software component generates activities such as programming or maintenance, in which manpower the main cost driver. For the case of software development, pools may not be independent if they share equipment or software development licenses (e.g. operating systems, compilers), or when pools share the cost of using a cloud computing model to use infrastructure, software applications or storage. This issue is related with cost allocation decisions (see Condition 1).

Also, if software or hardware engineers are shared by more than one pool, results would complement. For example, as a consequence of being part of a software development, a team acquires experience and knowledge. Then, when the same team works in another similar project, the team will require less working hours. In this case, the separable cost of each product is not equal to its stand alone cost.

The hardware component is related with activities such as physical product manufacturing (for example, a wind turbine, or a thermostat) and electronic manufacturing. $\mathrm{ABC}$ fundamentals were devised with a manufacturing firm in mind so many of its assumptions are naturally satisfied and its application is discussed elsewhere. Electronics devices are typically built by a vertical collection of companies in the supply chain. Then, companies outsource this activity and a cost allocation decision should be made (see Condition 1 and Illustrative example section). The major cost related with the communications component is storage for which there are two implementation alternatives: an in-house solution or a cloud computing where the company pays for what is used. For the in-house solution, storage derives activities related with storage and infrastructure management. The cloud computing alternative is more desirable, mainly for non-technological companies since it provides many benefits such as cost reduction in infrastructure or storage capacity, the availability of robust services, a reliable data management, and the scale possibility by contracting more space as soon as it is needed. A cost allocation decision regarding cloud computing services should be made (see Condition 1 and Illustrative example section). The remaining of this section is aim to provide a general understanding of the conditions which are needed to impose on $\mathrm{ABC}$ to be used to minimize costs. Browming and Hong (2007) indicate under what conditions cost functions can be shown to satisfy the requirements of accounting separability needed for $\mathrm{ABC}$ assumptions: conditions relating to technology, to the accounting system and to input prices.

\subsection{Conditions relating to technology}

Galbraith (1985) defines technology as the systematic application of scientific or other organized knowledge to practical tasks. Galbraith developed this definition with a manufacturing process in mind. In our case, all activities in a IoT company are modeled as an economic production process. In the discussion, the focus is on software development, IoT product monitoring and data analytics since they 
are the typical activities in this type of enterprise and for which $\mathrm{ABC}$ assumptions seem more difficult to satisfy.

Condition 1. That technology be non-joint in inputs meaning that there are no economies or diseconomies of joint production. A technology is non-joint if and only if there exists separate individual input requirement sets $V_{j}\left(y_{j}\right)$ for all products where the sum of individual inputs requirements is equal to the total input requirement $V(y)$ :

$$
V(y)=V_{1}\left(y_{1}\right)+\cdots+V_{n}\left(y_{n}\right)
$$

This condition is not always met in the case of software development where it is usual to reuse code or develop similar components, in which case there are activities that may be omitted (a software component reuse) or demand fewer working hours because the team leverages the knowledge or experience acquired previously. The future marginal cost decreases due to the production of similar products. In this case, inputs are not independent. As a consequence, in a cancel or postpone project decision, the decision maker should take into account the impact on manpower required to complete another software project. The $\mathrm{ABC}$-based costing information will not reflect this information.

The condition of non-jointness can be written in terms of cost pool costs. Based on this expression Bromwich and Hong (1999) state that the condition of no economies or diseconomies of scope either within or between cost pools is necessary and sufficient for the cost function to exhibit non-jointness. For the case of an enterprise producing smart and connected products it is usual to define a portfolio of a family of products in which case cost pools might not be independent. This explains the relevance of not dropping a product or that incremental costs might not be generated if another product (and hence an activity) is added.

Different software products share the use of application development licenses (compilers, operating systems) or equipment. A similar reasoning may be applied to electronic components design. A quite similar situation arises with the cost allocation of rent facilities. Some practitioners allocate them to cost centers on the basis of machine hours, or manpower. As a consequence, the estimates for product and activity costs may be too high. According to Noreen (1991) an ABC system will provide relevant data only if the cost in every cost pool is strictly proportional to its activity measure. Hence, it would be advisable not to allocate these costs to the product level.

In any of these scenarios, operations in one cost pool might affect the costs of another cost pools.

Condition 2. That the inputs within a cost pool can be aggregated into a single overall input; that is inputs are locally separable (an aggregate cost driver measure $h_{j}^{k}\left(x^{k}\right)$ ). This means that the bundles of elementary input can be aggregated using some input volume index (Bromwich \& Hong, 1999). Separability of technology is only required for each cost pool, it is possible to treat each cost pool as if it were associated with a separate production function producing a single intermediate output. The discussion about the satisfaction of this condition is similar to condition 1.

Condition 3. That technology for each cost pool is homothetic. A production function is homothetic if it can be expresses as an increasing transform of a linear homogeneous function. The literature on the software development industry contains references to returns-to-scale as a factor in software development productivity (Byrnes et al., 1993; Banker, 1984). Byrnes et al. (1993) estimate several models for software development in a production framework (with labor and tools employed as inputs) and conclude that increasing returns-to-scale are associated with small projects; and decreasing returnsto-scale are associated with larger projects. More recently, Gurbaxani et al. (2000) empirically study the use of the Cobb-Douglas production function in studies of information systems production conducted at the firm level. The authors model the production process for information services using a production function that transform hardware and personnel into information services. While the authors are not conclusive regarding the degree of substitutability between hardware and personnel, they assume constant elasticity of substitution for the time span considered in their study. Their results show that the production of information services is homothetic over the period analyzed. 


\subsection{Conditions relating to the accounting system}

Condition 4. That the aggregate input or cost driver for a cost pool is linearly homogeneous in the elementary inputs of the cost pool (Bromwich \& Hong, 1999). The necessary and sufficient conditions for a cost driver to accurately measure input consumption in its cost pool in the sense of accounting separability are that: (i) the production function for the cost pool is locally homothetic and non-joint; and (ii) the cost driver is linearly homogenous with regard to cost pool inputs (Bromwich \& Hong, 1999). While in principle, it may be accepted that an increase (decrease) in labor may result in more (less) output. For the case of software production it is not always the case. Many years ago, Brooks (1975) has already noted that the number of communication paths between project team members increases geometrically with the number of team members. This communication overhead is a factor that could contribute to decreasing returns to scale. Software development productivity is widely investigated in the software engineering literature (Boehm, 1981). More recently, Lavazza et al. (2018) provide evidence about how factors such as programming languages, business areas, architectural types, and the usage of specialized developing tools influence productivity. The smart products monitoring and data analytics may not comply with this condition for a cost driver to measure input consumption. Data analysis is performed over product units (to study individual functioning) and over aggregate data (to model use patterns or predict failures). The cost driver may be represented using manpower. However, it is not linearly related with the product units generating data. The object of cost might reflect another attributes that affect effort (in addition to volume): data variety (rain, humidity, temperature sensors, image data flows, engine rotations, etc.).

Condition 5. That the definition of activities requires that technology be separable to allow cost pools to be treated independently. Production function separability is concerned with whether a firm's production operations can be divided into a set of free standing hierarchical operations or technologies so that optimal decisions for each set of operations can be determined in isolation from other operations (Bromwich \& Hong, 1999). It is difficult to treat cost pools independently in a full extent. In other words, it is not always possible to define a set of cost pools satisfying this condition. For example, let the development of software applications supporting data analytics be a production function. Some attributes (application ease of use) of the result of this activity -the application software- affects the data analytics production function. Sometimes it may not be possible to identify cost pools and cost drivers consistent with technology separability, or its definition may not result a natural description of the organizational activities.

\subsection{Conditions relating to input prices}

Condition 6. That there is a perfect input market. By assuming perfect markets, the model ignores exchange consumption problems. Although real-world markets will probably never meet these criteria completely, they serve as a popular benchmark to identify market deficiencies that interfere with an efficient coordination (Kamerschen et al., 1989). Smart and connected products often introduce powerful new suppliers that manufacturers have never needed before: providers of sensors, software, connectivity, embedded operating systems, and data storage, analytics (Porter \& Heppelmann, 2014). Giants like Google or Apple have the capabilities that are essential to product differentiation and cost. The bargaining power of those new suppliers can be high, allowing them to capture a bigger share of overall product value and reduce manufacturers' profitability (Porter \& Heppelmann, 2014).

Condition 7. That the price index for a cost pool is invariant with volume and is a linear homogeneous function with regard to elementary input prices. The total cost of a cost pool $k, c^{k}(w, y)$ may be represented as:

$$
c^{k}(w, y)=\left\{h_{1}^{k}\left(x^{k}\right)+\cdots+h_{n}^{k}\left(x^{k}\right)\right\} c^{k}(w)
$$

where $h_{j}^{k}\left(x^{k}\right)$, for $j \in\{1, \cdots, n\}$ represents the amount of the aggregate input of cost pool $k$ used by product $j$ and $c^{k}(w)$ is a price index for the aggregate input in cost pool $k$ (Bromwich \& Hong, 1999). As described by Bromwich and Hong, to satisfy accounting separability, the price index for a group of 
factors must reflect the balance or mix of the resource consumption by products and must be constant for a given input price set for all products irrespective of the volume of the units of the cost driver consumed by products (homothetic technology). The input price index must also be linearly homogenous with respect to input prices which need to come from a perfect market. An illustration of the scenario in which the perfect market condition is not satisfied has been described previously.

This section aimed to discuss under what conditions an enterprise building and commercializing smart and connected products might rely on $\mathrm{ABC}$ cost information. Failure to satisfy these conditions leads to distorting accounting numbers away from economic costs (Bromwich \& Hong, Activity-based costing systems and incremental costs, 1999). It should be noted that the assumptions are common to both $\mathrm{ABC}$ and costs proportional to output volume. In order to conclude which are the practical impacts of not satisfying $\mathrm{ABC}$ assumptions, let consider the organizational purpose when building a cost system. Allen and Laurin (2018) argue that a cost system aimed at being simultaneously used in controlling and enabling ways can generate important difficulties. Controlling use aims to mitigate problems of information asymmetry, whereas enabling use seeks to reduce uncertainty and improve decision-making ((Sprinkle, 2003) as cited in (Allain \& Laurin, 2018)). A system used in a controlling way is designed to satisfy corporate accountants needs which focus on meeting regulatory requirements. Regulations require timely and accurate information. In addition, government agencies in some countries require accounting balance to be defined following full costing methods performing an allocation of all costs at the product level (Federación Argentina de Consejos Profesionales de Ciencias Económicas, 2002). Operational decision making requires detailed information, transparency to find the bearings inside the calculations, and a flexible software support to perform analysis. The processing of this information may require much effort. Finally, and with of the aim of framing this discussion in the IoT Business Model Patterns, the concern is on the effects of "Digitally charged products" and "Sensor as a service" on $\mathrm{ABC}$ cost information. In other words, do patterns derive activities with different implications over $\mathrm{ABC}$ assumptions? First, patterns as defined by Weinberg et al. (Weinberger, Bilgeri, \& Fleisch, 2016) focus on different ways of generating profits which is an issue of business profitability and is better approached by theories of competitive strategy (which are out o the scope of this paper). Regarding production functions, the "Digitally charged products" pattern is related with traditional manufacturing activities of physical products, software development and data analytics. The core activity emerging from the "Sensor as a service" pattern is data collecting, processing and selling. Both patterns require collecting data from the product and end-user behaviour in real time; analyze large volumes of data, and share it with other stakeholders. These activities are performed after sales and on a continuous basis so organizations need to focus on these costs in order to make long-term decisions. The following section aims to illustrate how a small enterprise may proceed to define its $\mathrm{ABC}$ costing system. The example also pretend to clarify some of the issues briefly discussed earlier.

\section{Illustrative example}

In order to illustrate the definition of an $\mathrm{ABC}$ cost system consider the following example. The company provides smart and connected product solutions for homes and small business. The case relates to "Digitally charged products" business model pattern (Fleisch, Weinberg, \& Wortman, 2014) where objects transmit data to the manufacturer over lifetime. The manufacturer can then use the data to improve the product.

The organizational structure includes unified data, information technology, research and development, marketing, sales, service and support, and finance. There is not a formal area for human resources.

Currently, the company is commercializes two smart products: a wind generator (which is under development) and a scale platform. The smart wind generator is designed for homes and businesses. It produces up to 20 kilowatt hours of clean electricity per month and comes with monitoring software to track the generator performance from a computer or smart phone. The frequency of preventive service 
increases as the physical product approaches obsolescence. In the next subsection, more details are provided about the product.

Table 2

Areas in the smart and connected products company

Unified data: a functional unit focused on data management. This unit consolidate data collection, aggregation, and analytics, and is responsible for making data available across all functions.

Information technology: IT engineers buy hardware and develop software. Supports TICs in all the company. The unit is responsible of developing the digital technologies that will differentiate the company in the market place (application servers and IoT analytic application). Team: 1 hardware and 2 software.

Research and development: develops the capabilities for combining mechanical electrical components, and incorporating software in products.

Marketing and sales: define and coordinate sales strategies. Locate and position the company in the market. Forecast demand and set prices.

Service and support: remote and local service to fix or upgrade software issues; using predictive analytics the team can anticipate signs of trouble and perform preventive service.

Administration, finance, legal: suppliers' contracts (storage, electronics, wind generator, scale platform).

Source: own elaboration.

Regarding the platform scale, the firm manufactures a scale to weight cattle. The platform is in front of the water through so each time a cow is thirsty it climbs the scale. Once on the scale and based on the sensors attached to its feet, the weight is recorded. An algorithm identifies individual weights and builds a weight profile over a period of time. A network composed of intelligent sensors collects useful data for cattle owners. For example, the daily gain of weight data supports decision making on diet planning, or early detection and prevention of diseases. Information can be accessed in real-time on-site or offsite, and with a smart phone or with a desktop computer. The option that includes smart phone access requires internet connection.

\subsection{Description of the smart and connected wind generator}

The software component. The software is aimed to implement the IoT analytics. There are two applications: one aimed for the customer and another to support the Unified Data unit work. The customer application is web application that can be accessed using a user name and password.

For both applications, the main activities are to develop a project management plan (is the process of documenting the actions necessary to define, prepare, integrate, and coordinate all subsidiary plans); requirements (is the process of defining and documenting stakeholders' needs to meet the project objectives), analysis, design, implementation, and testing.

The physical product. The manufacturing of the wind turbine components is outsourced. The hardware defined product consists of the hardware required to capture, process, and transmit data. This comprises the embedded system and the sensors and actuators. The embedded system consists of a microcomputer board (microprocessor, memory, power supply and some communication components like Bluetooth, LORA, or wifi). Sensors and actuators are connected to this board. The design of the electronic components is in charge of the hardware team and the manufacturing is outsourced.

The communication component. The purpose of the communication layer is to transmit data to a server. This is the IoT communication. Data storage in the cloud is outsourced. The cloud contains the application servers that run the non-resident applications and databases.

The core activities are related to the following

a) new smart and connected products development,

b) installation of a smart wind generator

c) installation of a smart scale

d) smart and connected products monitoring (service and support)

e) IoT analytics (unified data functional unit) 
The activities involved in the installation of a smart wind generator are as follows: install the foundation, erect the turbine, and connect it to the house meter. There are some authorized technicians located in different regions responsible for the installation of a smart wind generator or a smart scale.

A detailed description of the core activities is included in Appendix A (Tables A.1 to A.4). Fig. 1 summarizes the smart wind generator value proposition using the Innovation Canvas template.

\begin{tabular}{|c|c|c|c|c|c|}
\hline Explore & Stories & External Systems & \multirow{2}{*}{\multicolumn{3}{|c|}{$\begin{array}{l}\text { Key Functions } \\
\text {-Produce clean electricity. } \\
\text {-Track generator performance. }\end{array}$}} \\
\hline $\begin{array}{l}\text { Opportunity identification } \\
\text {-Need for efficient sources of energy. } \\
\text {-Autonomous energy system. }\end{array}$ & $\begin{array}{l}\text {-Wind turbines } \\
\text { work with } \\
\text { utility-connected } \\
\text { homes. } \\
\text {-Smart business } \\
\text { solution } \\
\text { (supermarkets, } \\
\text { warehouses, } \\
\text { factories, hotels). }\end{array}$ & $\begin{array}{l}\text {-IoT analytics } \\
\text { software. } \\
\text {-Remote service } \\
\text { to fix or upgrade } \\
\text { software. } \\
\text {-Preventive } \\
\text { service. }\end{array}$ & & & \\
\hline $\begin{array}{l}\text { Learning } \\
\text {-Feedback from first clients. }\end{array}$ & \multirow{2}{*}{\multicolumn{2}{|c|}{$\begin{array}{l}\text { Value } \\
\text {-Clean and sustainable energy generation. } \\
\text {-Reduction of electric bills. }\end{array}$}} & \multicolumn{3}{|c|}{$\begin{array}{l}\text { Key features } \\
\text {-Quiet operation. } \\
\text {-Web-based performance monitoring software. } \\
\text {-Preventive service }\end{array}$} \\
\hline $\begin{array}{l}\text { Critical to success } \\
\text {-Compliance with current standards for small turbines. } \\
\text {-Production of energy in very low wind speeds. } \\
\text {-Survival wind speed of } 140 \mathrm{mph} \text {. }\end{array}$ & & & \multicolumn{3}{|c|}{$\begin{array}{l}\text { Revenue stream } \\
\text {-Wind generator sales. } \\
\text {-Service maintenance fee. }\end{array}$} \\
\hline $\begin{array}{l}\text {-Software components (customer application, } \\
\text { unifed data unit work). } \\
\text {-Physical product (wind turbine, electronic } \\
\text { components). } \\
\text {-Communication component (storage). }\end{array}$ & $\begin{array}{l}\text { Critical risks } \\
\text {-Data security. } \\
\text {-Connectivity. } \\
\text {-Zoning } \\
\text { regulations } \\
\text { limiting the } \\
\text { height, } \\
\text { placement, and } \\
\text { other } \\
\text { characteristics. }\end{array}$ & $\begin{array}{l}\text { Cost Structure } \\
\text {-Labour. } \\
\text {-Industrial } \\
\text { building. } \\
\text {-Office } \\
\text { equipment. } \\
\text {-External } \\
\text { activities. }\end{array}$ & $\begin{array}{l}\text { Customer } \\
\text { Segments } \\
\text {-Homes. } \\
\text {-Businesses. } \\
\\
\text { Key partners } \\
\text {-Wind generators' } \\
\text { manufacturers. } \\
\text {-Electronic } \\
\text { components' } \\
\text { manufacturers. } \\
\text {-Cloud computing. }\end{array}$ & $\begin{array}{l}\text { Channels } \\
\text {-Direct sales. } \\
\text {-Distribution } \\
\text { (delivery). } \\
\\
\text { Key activities } \\
\text {-Development. } \\
\text {-Installation. } \\
\text {-Monitoring. } \\
\text {-IoT analytics. }\end{array}$ & \begin{tabular}{l} 
Customer relationships \\
-Remote and local \\
serveces. \\
-Different \\
traditional media. \\
Key resources \\
-Financial resources. \\
-Software team. \\
-Hardware team. \\
-Data scients. \\
-Cloud services. \\
\multicolumn{1}{l}{ Market }
\end{tabular} \\
\hline
\end{tabular}

Source: own elaboration.

Fig. 1. Business Model for Smart Wind Generator based on the Innovation Canvas.

\subsection{ABC cost structure}

An $\mathrm{ABC}$ study is presented to determine the costs for the two products. For space reasons, only "IoT Analytics" activity is described. This activity is of different nature when compared with traditional manufacturing activities. This activity and "Smart and connected products monitoring" include tasks that initiate after sales. Hence, the following results serve as a reference to forecast future expenditures during the life of the products.

First, primary activities are identified as the cost centres. Activity costs are allocated to product cost using a cost driver. Cost driver rate is equal to the total cost of activity divided by the total number of cost object (see Table 3 ).

The accounting system accumulates costs for a period of time. For a control purpose, this period is defined by a regulatory body and it is usually a year. For an operational purpose (enabling use) the period may be shorter. In this case, we consider 52 working weeks in a year, and working days sum up to 252. For an eight hours workday, each employee works 2,016 hours a year. There is one employee at the Unified Data. The annual expense (work salaries including benefits) per employee is US\$20,318.50. Each semester the firm offers a training course and the cost is US\$666.67.

In this case, indirect costs are allocated at the product level. This is required to comply with regulations. However, since the criterion to determine the proportion to be allocated is quite subjective, the activity assessment may become confusing (in a decision-making scenario). Let describe the criteria used in this example. 
Table 3

The ABC implementation flow chart

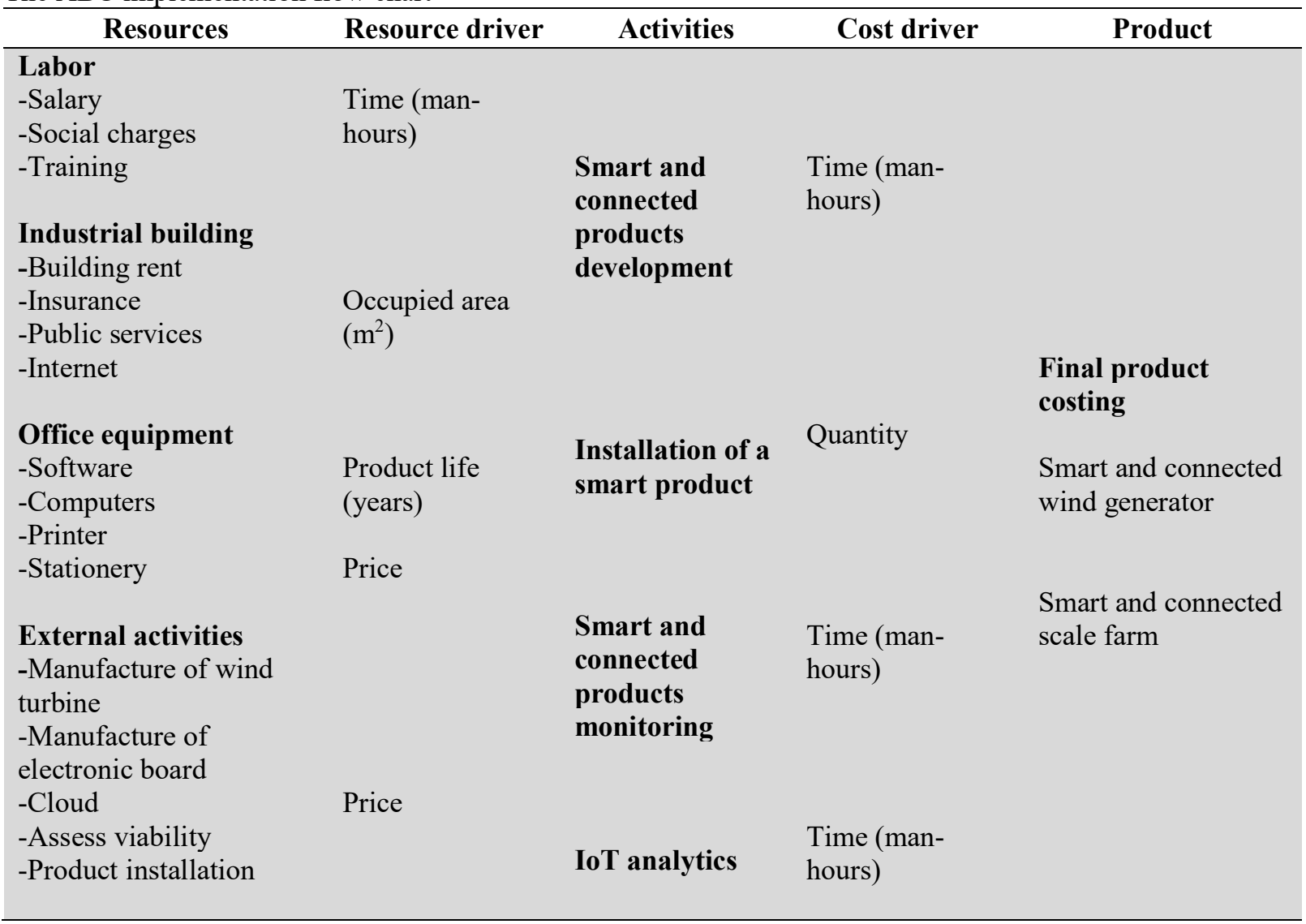

Source: own elaboration.

The analytics software is classified as an intangible asset according to accountancy international laws (International Accounting Standards Board , 2008). The obsolescence of the software is estimated in two years as a result of the speed of technological changes. Since the product life can be defined, the cost of obsolesce is computed. Hardware depreciation is calculated based on five years of product service life. The software cost is US\$4,444.44 and the hardware equipment cost is US\$844.44. Regarding cloud storage (outsourced to a cloud computing service provider), the annual cost is of US\$693.33, and a 30\% is allocated to "IoT Analytics" cost centre. Stationary expenditures are allocated in the same proportion to each area and hence US\$212.89 is assigned to the IoT Analytics activity. The building rental and insurance costs are assigned considering the square meters occupied by each office. The building has an area of 90 square meters and Unified Data where IoT Analytics is developed occupies 20 square meters. Adding up all these costs, the total cost of IoT Analytics is of US\$25,382.35 (see Table B.1).

Based on the ABC system, the cost of the smart wind generator is US\$6,091.76 (see Table B.3). For a decision-making purpose, it is useful to consider that if indirect costs are not allocated to each product, then the cost would be $7.9 \%$ less (US\$5,610.13).

The $\mathrm{ABC}$ effort forces the organization to look hard at what activities exist, why they engage in those activities and the amount of time and indirect costs that each one takes for each product. 


\section{Conclusions}

This work provides a first discussion of the implications of the use of an $\mathrm{ABC}$ costing approach for small enterprises building and commercializing smart and connected products. The conditions required for $\mathrm{ABC}$ systems to accurately reflect avoidable product costs and incremental activity cost are quite strong. In particular, they are more difficult to be satisfied by the kind of company described in this work. However, as stated by Noreen (1991), this is true of traditional costing systems, which are special cases of $\mathrm{ABC}$.

An important issue that emerges from the analysis is that cost is a function of the volume of production and this notion of production does not represent the source of value generation discussed in this work. Manufacturing now goes beyond the production of the physical object, because a functioning smart and connected product requires a cloud-based system for operating it throughout its life (Porter \& Heppelmann, 2015). And this after-sales monitoring generates costs that are not allocated to products when the manufacture/not manufacture decision is taken. Value is created by collecting product behaviour data and preparing it in beneficial ways for internal use or interested third parties. The implication of collecting and processing data is that costs essentially changes depending on the volume of data stored and the complexity of intended analytics that would require more qualified analysts. The cost estimation of activities related with data analytics and products' monitoring serve as a reference to forecast future expending during the lifetime of products.

The analysis presented in this work is subject to some limitations. The definition of cost structure is based on management accounting that focuses on production and ignores exchange consumption problems by assuming perfect and complete markets. The analysis of this topic is out of the scope of this paper and the reader is referred to Bromwich (2007).

\section{References}

Ahmed, J., Rogge, R., Kline, W., Bunch, R., Mason, T., Wollowski, M., et al. (2014). The innovation canvas: An instructor's guide. 121st ASEE Annual Conference and Exposition (pp. 1-12). Indianapolis: American Society for Engineering Education.

Allain, E., \& Laurin, C. (2018). Explaining implementation difficulties associated with activity-based costing through system uses. Journal of Applied Accounting Research , 19 (1), 181-198.

Ashton, K. (2009). That "Internet of Things" thing. RFID Journal , 22, 97-114.

Askarany, D., Yazdifar, H., \& Askary, S. (2010). Supply chain management, activity-based costing and organisational factors. International Journal of Production Economics , 127 (2), 238-248.

Banker, R. (1984). Estimating most productive scale size using Data Envelopment Analysis. European Journal of Operational Research (17), 35-44.

Blaschke, M., Cigaina, M., Riss, U., \& Shoshan, I. (2017). Designing Business Models for the Digital Economy. In Shaping the Digital Enterprise.

Boehm, B. (1981). Software Engineering Economics. Upper Saddle River: Prentice Hall PTR.

Bromwich, M. (2007). Economics in Management Accounting. En C. Chapman, A. Hopwood, \& M. Shields (Edits.), Handbooks of Management Accounting Research (págs. 137-162). Elsevier.

Bromwich, M., \& Hong, C. (1999). Activity-based costing systems and incremental costs. Management Accounting Research, 10, 39-60.

Brooks, F. (1975). The Mythical Man-Month. Reading: Addison-Wesley.

Byrnes, P., Frazier, T., \& Gulledge, T. (1993). Returns-to-scale in software production: a comparison of approaches. In T. Gulledge, \& W. Hutzler (Eds.), Analytical methods in software engineering economics (pp. 75-97). Berlin: Springer.

Canvanizer 2.0. (2017, 4 18). Canvanizer. Retrieved from https://canvanizer.com/new/openinnovation-canvas 
Chambers, R. (1988). Applied Production Analysis: A Dual Approach. Cambridge: Cambridge University Press.

Conti, M., Das, S., Bisdikian, M., Kumar, M., Ni, L., Passarella, A., et al. (2012). Looking ahead in pervasive computing: Challenges and opportunities in the era of cyberphysical convergence. Pervasive and Mobile Computing , 8 (1), 2-21.

Federación Argentina de Consejos Profesionales de Ciencias Económicas. (2002). Resolución Técnica $\mathrm{N}^{\circ}$ 17. Normas Contables Profesionales: Desarrollo de Cuestiones de Aplicación General . República Argentina: FACPCE.

Fleisch, E., Weinberg, M., \& Wortman, F. (2014). Business Models and the Internet of Things. Bosch IoT Lab White Paper, A Cooperation of University of Saint Gallen and Bosch, Bosch Internet of Things \& Services Lab.

Galbraith, J. (1985). The New Industrial State. Boston: Houghton-Mifflin.

Gassmann, O., Frankenberger, K., \& Csik, M. (2014). The business model navigator: 55 models that will revolutionise your business. London: Pearson.

Gosselin, M. (2007). A Review of Activity-Based Costing: Technique, Implementation, and Consequences. In C. Chapman, A. Hopwood, \& M. Shields (Eds.), Handbook of Managing Accounting Research (pp. 641-671). Elsevier Ltd.

Govindarajan, V., \& Immelt, J. (2019). The Only Way Manufacturers Can Survive. MIT Sloan Management Review, Spring issue.

Gubbi, J., Buyya, R., Marusic, S., \& Palaniswami, M. (2013). Internet of Things (IoT): a vision, architectural elements, and future directions. Future Generation Computer Systems , 29 (7), 1645 1660.

Guo, L., Wei, Y., Sharma, R., \& Rong, K. (2017). "Investigating e-business models' value retention for start-ups: The moderating role of venture capital investment intensity. International Journal of Production Economics , 186, 33-45.

Gurbaxani, V., Melville, N., \& Kraemer, K. (2000). The Production of Information Services: A FirmLevel Analysis of Information Systems Budgets. Information Systems Research, 11 (2), 159-176.

Hilton, R. (2005). Managerial accounting: creating value in a dynamic business environment. New York: McGraw-Hill/Irwin.

International Accounting Standards Board . (2008). International Accounting Standard 38.

Kline, W., Hixson, C., Mason, T., Brackin, P., Bunch, R., Dee, K., et al. (2013). The Innovation Canvas - A Tool to Develop Integrated Product Designs and Business Models. 120th ASEE Annual Conference and Exposition (pp. 1-11). Atlanta: American Society for Engineering Education.

Lavazza, L., Morasca, S., \& Tosi, D. (2018). An empirical study on the factors affecting software development productivity. E-Informatica Software Engineering Journal , 12 (1), 27-49.

McAfee, A., \& Brynjolfsson, E. (2017). Machine, Platform, Crowd. Harnessing our digital future. New York: W. W. Norton \& Company Ltd.

Medeiros, H., Santana, A., \& Guimarães, L. (2017). The use of costing methods in lean manufacturing industries: a literature review. Gestão \& Produção , 24 (2), 395-406.

Metallo, C., Agrifoglio, R., Schiavone, F., \& Mueller, J. Understanding business model in the Internet of Things industry. Technological Forecasting \& Social Change, In press.

Noreen, E. (1991). Conditions under which Activity-Based Costs systems provide relevant costs. Journal of Management Accounting Research , 3, 159-168.

Olson, N., Nolin, J., \& Nelhans, G. (2015). Semantic web, ubiquitous computing, or internet of things? A macro-analysis of scholarly publications. Journal of Documentation , 71 (5), 884-916.

Onar, S., \& Ustundag, A. (2018). Smart and Connected Product Business Models. En A. Ustundag, \& E. Cevikcan (Edits.), Industry 4.0: Managing the Digital Transformation (págs. 25-41). Springer International Publishing Switzerland.

Orwat, C., Graefe, A., \& Faulwasser, T. (2008). Towards pervasive computing in health care - A literature review. Bmc Medical Informatics and Decision Making , 8 (26).

Osterwalder, A., \& Pigneur, Y. (2010). Business Model Generation: A Handbook for Visionaries, Game Changers, and Challengers. Hoboken: John Wiley \& Sons, Inc. 
Osterwalder, A., Pigneur, Y., \& Tucci, C. (2005). Clarifying business models: origins, present, and future of the concept. Communications of the Association for Information Systems , 15, 1-25.

Porter, M., \& Heppelmann, J. (2015). How Smart, Connected Products are Transforming Companies. Harvard Business Review , 1-19.

Porter, M., \& Heppelmann, J. (2014). How Smart, Connected Products Are Transforming Competition. Harvard Business Review , 4-23.

Sinclair, B. (2017). IoT Inc. How your Company can Use the Internet of Things to Win in the Outcome Economy. (F. edition, Ed.) San Francisco: McGraw Hill Education.

Sprinkle, G. (2003). Perspectives on experimental research in managerial accounting. Accounting, Organizations and Society, 28, 287-318.

Weinberger, M., Bilgeri, D., \& Fleisch, E. (2016). IoT business models in an industrial context. atAutomatisierungstechnik, 64 (9), 699-706.

Weiser, M. (1991). The computer for the twenty-first century. Scientific American , 290, 46-55.

Westerman, G., Bonnet, D., \& McAfee, A. (2014). Leading digital: turning technology into business transformation. Boston: Harvard Business Review Press.

Willness, C., \& Bruni-Bossio, V. (2017). The curriculum innovation canvas: A design thinking framework for the engaged educational entrepreneur. Journal of Higher Education Outreach and Engagement , 21 (1), 134-164.

\section{Appendix A. Detail of some of the core activities}

Table A.1

Description of the main activity "New smart and connected products development"

\begin{tabular}{|c|c|c|c|}
\hline \multicolumn{2}{|r|}{ Sub-activities } & \multicolumn{2}{|l|}{ Area } \\
\hline 1. & $\begin{array}{l}\text { Develop a detailed description of the project goals, collect stakeholder and voice of the customer input, clarify } \\
\text { benefits and values of a product and provide context for the project. }\end{array}$ & $\begin{array}{l}\text { Information } \\
\text { R\&D }\end{array}$ & technology, \\
\hline 2. & Describe what the product will do and the external systems that the product interacts with. & $\begin{array}{l}\text { Information } \\
\text { R\&D }\end{array}$ & technology, \\
\hline 3. & $\begin{array}{l}\text { Design. Develop a formal requirements analysis, key components or modules, critical success factors of the } \\
\text { product, and critical risks of product failure that require special attention. }\end{array}$ & $\begin{array}{l}\text { Information } \\
\text { R\&D }\end{array}$ & technology, \\
\hline 4. & Implementation of customer web application (software implementation and testing). & $\begin{array}{l}\text { Information } \\
\text { (software team) }\end{array}$ & technology \\
\hline 5. & Implementation of Unified Data unit application (software implementation and testing). & $\begin{array}{l}\text { Information } \\
\text { (software team) }\end{array}$ & technology \\
\hline 6. & Design of the electronic components. & $\begin{array}{l}\text { Information } \\
\text { (hardware team) }\end{array}$ & technology \\
\hline 7. & Assemble of wind turbine and electronic components for testing. & $\begin{array}{l}\text { Information } \\
\text { (hardware team) }\end{array}$ & technology \\
\hline
\end{tabular}

Source: own elaboration.

Table A.2

Description of the main activity "Installation of a smart wind generator"

\begin{tabular}{|c|c|c|}
\hline & Area & External activity \\
\hline 1. Visit customer house to assess viability of installation. & & $\begin{array}{l}\text { Local } \\
\text { technicians. }\end{array}$ \\
\hline 2. Assemble of wind turbine and electronic components. & $\begin{array}{l}\text { Information } \\
\text { technology (hardware } \\
\text { team) }\end{array}$ & \\
\hline $\begin{array}{l}\text { 3. Installation. Install the foundation, erect the turbine, and connect it to } \\
\text { the house meter. }\end{array}$ & & $\begin{array}{l}\text { Local } \\
\text { technicians. }\end{array}$ \\
\hline 4. Define new customer profile to access web application. & $\begin{array}{l}\text { Information } \\
\text { technology (software } \\
\text { team). }\end{array}$ & \\
\hline
\end{tabular}

Source: own elaboration. 
Table A.3

Description of the main activity "Smart and connected products monitoring

\begin{tabular}{llll}
\hline & & \multicolumn{1}{c}{ Area } & \multicolumn{1}{c}{ External activity } \\
\hline Remote service to fix or upgrade software. & $\begin{array}{l}\text { Service and support, } \\
\text { Information } \\
\text { technology (software } \\
\text { team) }\end{array}$ & Service and support. & Local technicians \\
\hline
\end{tabular}

Source: own elaboration.

Table A.4

Description of the main activity "IoT analytics"

Area

1. Consolidate strategy for data collection, data aggregation and data analysis. Unified data

2. Descriptive analytics to understand what happened in the past (patterns of use, energy Unified data generated)

3. Predictive analytics to estimate when a part is going to break.

Unified data

Source: own elaboration.

\section{Appendix B. ABC costing system (partial view)}

Table B.1

Cost description for IoT Analytics activity

\begin{tabular}{|c|c|c|c|c|c|}
\hline $\begin{array}{c}\text { Main Activity: IoT } \\
\text { Analytics }\end{array}$ & Inductor & $\begin{array}{c}\text { Total } \\
\text { resource } \\
\text { weighting }\end{array}$ & $\begin{array}{l}\text { Sub-activity } \\
\text { weight }\end{array}$ & $\begin{array}{l}\text { Area resource } \\
\text { driver rate }\end{array}$ & $\begin{array}{l}\text { Activity cost } \\
\text { (USD) }\end{array}$ \\
\hline $\begin{array}{l}\text { 1. Consolidate strategy for } \\
\text { data collection, data } \\
\text { aggregation and data } \\
\text { analysis. }\end{array}$ & Man-hour & 2,016 & 403.20 & 0.20 & $5,076.47$ \\
\hline $\begin{array}{l}\text { 2. Descriptive analytics to } \\
\text { understand what happened } \\
\text { in the past. }\end{array}$ & Man-hour & 2,016 & 806.40 & 0.40 & $10,152.94$ \\
\hline $\begin{array}{l}\text { 3. Predictive analytics to } \\
\text { estimate when a part is } \\
\text { going to break. }\end{array}$ & Man-hour & 2,016 & 806.40 & 0.40 & $10,152.94$ \\
\hline Total & & 2,016 & $2,016.00$ & & $25,382.35$ \\
\hline
\end{tabular}

Source: own elaboration.

Table B.2

Cost driver rate estimation based on hours allocated to each product

Cost centre activities

1. Consolidate strategy for data collection, data aggregation and data analysis.

2. Descriptive analytics to understand what happened in the past (patterns of use, energy generated)

3. Predictive analytics to estimate when a part is going to break.

Source: own elaboration.
Total cost of Product activity (USD)
Platform Scale Wind generator

201.60

Hours spent in activities

201.60

4.47

$\begin{array}{llll}10,152 ., 94 & 685.44 & 120.96 & 806.40\end{array}$

$10,152.94$

645.12

161.28

806.40

14.47

Cost driver rate 
Table B.3

Product cost estimation

\begin{tabular}{lrr}
\hline Activities & Platform Scale & Wind generator \\
\hline $\begin{array}{lr}\text { 1. Consolidate strategy for data collection, data aggregation and data analysis. } \\
\text { 2. Descriptive analytics to understand what happened in the past (patterns of }\end{array}$ & $2,538.23$ & $2,538.23$ \\
$\begin{array}{l}\text { use, energy generated) } \\
\text { 3. Predictive analytics to estimate when a part is going to break. }\end{array}$ & $8,630.00$ & $1,522.94$ \\
& $8,122.35$ & $6,030.59$ \\
\hline
\end{tabular}

Source: own elaboration.

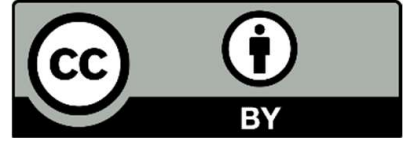

(C) 2020 by the authors; licensee Growing Science, Canada. This is an open access article distributed under the terms and conditions of the Creative Commons Attribution (CC-BY) license (http://creativecommons.org/licenses/by/4.0/). 